\title{
Effects of Salt Concentration in Soybean Sauce on the Physicochemical Properties of Pre-rigor Ground Hanwoo Muscle
}

\author{
Hyun-Wook Kim¹, Ji-Hun Choi ${ }^{1}$, Yun-Sang Choi², Hack-Youn Kim², Doo-Jeong Han ${ }^{1}$, \\ Tae-Hyun Kim${ }^{1}$, Sung-Ki Lee ${ }^{3}$, and Cheon-Jei Kim ${ }^{1,2 *}$ \\ ${ }^{1}$ Department of Food Science and Biotechnology of Animal Resources, Konkuk University, Seoul 143-701, Korea \\ ${ }^{2}$ Research Institute for Meat Science and Culture, Konkuk University, Seoul 143-701, Korea \\ ${ }^{3}$ Department of Animal Products and Food Science, Kangwon National University, Chuncheon 200-701, Korea
}

\begin{abstract}
This study was conducted to examine the effect of salt concentration in soybean sauce (ganjang) on pre-rigor ground Hanwoo (Korean native cattle) muscle. Although adding soybean sauce reduced $\mathrm{pH}$ of pre-rigor Hanwoo muscle, it improved the water holding capacity (WHC), cooking loss, total protein solubility, myofibrillar fragmentation index (MFI), 2-thiobarbituric acid (TBA) values, and textural properties by increasing salt concentration in the soybean sauce. In particular, adding soybean sauce inhibited lipid oxidation despite increasing salt concentration. An increased salt concentration in the soybean sauce in pre-rigor Hanwoo muscle tended to make the meat have lower lightness and higher redness and yellowness values. Although soybean sauce had a significantly lower pre-rigor salting effect than sodium chloride in terms of cooking loss and total protein solubility $(p<0.05)$, soybean sauce improved myofibrillar fragmentation and lipid oxidation when compared with sodium chloride. Furthermore, no significant differences in textural properties were observed between adding soybean sauce and sodium chloride at the same salt concentrations. Therefore, soybean sauce can be a functional curing material for pre-rigor muscle.
\end{abstract}

Key words: soybean sauce, pre-rigor muscle, Hanwoo, pre-rigor salting effect

\section{Introduction}

In Korea, soybean sauce has been utilized as a marinade source on a variety of Korean traditional meat products, such as bulgogi (Korean style barbecued beef), galbi-jjim (braised short ribs), and tteok-galbi (grilled short rib patties), which are traditionally produced by using Korean native cattle (Hanwoo). Demand for these meat products by foreigners has been increasing due to the characteristic flavor and taste of meats containing soybean sauce. Soybean sauce is a fermented food derived from soybean and Korean soybean sauce has been named ganjang. This soybean sauce contains a high salt concentration (approximately 15-20\%), water (approximately $50-70 \%$ ), and various compounds derived from the soybeans during fermentation such as isoflavon, amino acids, organic acids, and melanoidin (Jeon et al., 2002; Kim et

*Corresponding author: Cheon-Jei Kim, Department of Food Science and Biotechnology of Animal Resources, Konkuk University, Seoul 143-701, Korea. Tel: 82-2-450-3684, Fax: 82-2-444-6695, E-mail: kimcj@konkuk.ac.kr al., 2002; Shim et al., 2008). Melanoidin is produced by maillard reaction, and the color characteristics of the soybean sauce are affected by melanoidins (Moon, 1991). In addition, the melanoidin in soybean sauce has an antioxidative effect against lipid oxidation of beef meat (Choi et al., 1990). Recently, many studies have examined the effects of soybean sauce on the physicochemical properties and quality characteristics of meat and meat products (Choi et al., 2006; Jin et al., 2004; Kim et al., 2011).

Utilization of pre-rigor muscles, which are treated by hot-boned processing or accelerated processing, has many advantages, including a reduction in cooler space, decrease of energy cost and an increase in final yield as well as the improvement of meat functionalities (Hamm, 1981; Pisula and Tyburcy, 1996). Bernthal et al. (1989) reported that pre-rigor meat containing salt has better physicochemical properties than post-rigor meat. In addition, Boles and Swan (1997) showed that the type of brine ingredients affects the meat properties of both preand post-rigor beef. However, the effects of soybean sauce concentration on pre-rigor Hanwoo (Korean native cattle) muscle have not yet established. Although there is 
a study exploring the effects of soybean sauce on physicochemical properties of frozen Hanwoo patties (Kim et al., 2011), limited research has been conducted for the comparison of pre-rigor ground Hanwoo muscle containing various concentrations of soybean sauce. Thus, it is necessary to evaluate the effect of soybean sauce concentrations as a functional marinade ingredient on pre-rigor ground Hanwoo muscle for globalization of Korean food and the improvement of quality properties in Korean meat products

Therefore, the objective of this study was to investigate the effects of various soybean sauce concentrations on the physicochemical properties of pre-rigor Hanwoo muscle.

\section{Materials and Methods}

\section{Raw material collection and sample preparation}

A total of twelve Hanwoo cows (each of four Hanwoo cows in three replications, 24 mon of age; live weights, $774.2 \mathrm{~kg}$; slaughter weights, $470.0 \mathrm{~kg}$ ) were slaughtered at a local municipal slaughterhouse. After splitting and bleeding, the carcasses were transferred to the cutting room. Individual Semimembranosus muscles (SM) were removed immediately from the carcasses, and trimmed of visible fat and connective tissue. SMs were placed in polyethylene bags in insulated ice bag and transported to the Meat Science Laboratory at Konkuk University, Korea. SMs were initially ground through an $8 \mathrm{~mm}$ plate (PM100, Mainca, Spain) within $1 \mathrm{~h}$ from the beginning of slaughter, and then randomly assigned to five treatment groups.

Commercial soybean sauce (Fermented soybean sauce, Sempio Foods Co., Korea) was purchased from the local market (Table 1). Soybean sauce solutions, which were diluted with ice water, were made at three different target salt concentrations $(0.5,1.0$, and $2.0 \% \mathrm{w} / \mathrm{w})$ based on the sample weight, and sodium chloride solution was also prepared $(2.0 \%$ of total salt concentration based on the sample weight). These soybean sauce and sodium chloride solutions were individually added to pre-rigor ground Hanwoo muscle (Table 2). Samples were mixed by hand for $5 \mathrm{~min}$, and then analyzed immediately, except for 2 -

Table 1. Physicochemical properties of soybean sauce

\begin{tabular}{cccccc}
\hline \hline $\mathrm{pH}$ & $\begin{array}{c}\mathrm{NaCl} \\
(\%)\end{array}$ & $\begin{array}{c}\mathrm{TN}^{1)} \\
(\%)\end{array}$ & $\begin{array}{c}\mathrm{CIE} \\
\mathrm{L}^{*}\end{array}$ & $\begin{array}{c}\text { CIE } \\
\mathrm{a}^{*}\end{array}$ & $\begin{array}{c}\mathrm{CIE} \\
\mathrm{b}^{*}\end{array}$ \\
\hline 4.95 & 16.0 & 1.55 & $8.64 \pm 0.32^{2)}$ & $-0.32 \pm 0.34$ & $1.89 \pm 0.20$ \\
\hline
\end{tabular}

${ }^{1)} \mathrm{TN}$ : total nitrogen

${ }^{2)}$ All values are mean $\pm \mathrm{SD}$.
Table 2. Formulation for the samples preparation

(Unit: \%)

\begin{tabular}{|c|c|c|c|c|c|}
\hline \multirow{2}{*}{ ngredient } & \multirow{2}{*}{ Control } & \multicolumn{4}{|c|}{ Treatments ${ }^{3)}$} \\
\hline & & TS & $\mathrm{T} 1$ & $\mathrm{~T} 2$ & $\mathrm{~T} 3$ \\
\hline e-rigor Han & 80 & 80 & 80 & 80 & 80 \\
\hline oybean sauce solution ${ }^{1)}$ & - & - & 20 & 20 & 20 \\
\hline solution ${ }^{2)}$ & - & 20 & - & - & - \\
\hline we & 20 & - & - & - & - \\
\hline tal & 100 & 100 & 100 & 100 & 100 \\
\hline otal salt con & 0.0 & 2.0 & 0. & 1.0 & 2.0 \\
\hline \multicolumn{6}{|c|}{$\begin{array}{l}{ }^{1)} \text { Soybean sauce solution: liquid soybean sauce diluted by ice } \\
\text { water }\end{array}$} \\
\hline \multicolumn{6}{|c|}{$\begin{array}{l}{ }^{2)} \text { Sodium chloride solution: purified sodium chloride dissolved in } \\
\text { ice water }\end{array}$} \\
\hline \multicolumn{6}{|c|}{$\begin{array}{l}{ }^{3)} \text { Treatments: Control, pre-rigor ground Hanwoo muscle was } \\
\text { mixed with ice water (total salt concentration, } 0 \% \text { ); TS, pre- } \\
\text { rigor ground Hanwoo muscle was mixed with sodium chloride } \\
\text { solution (total salt concentration, } 2 \% \text { ); } \mathrm{T} 1, \mathrm{~T} 2 \text {, and } \mathrm{T} 3 \text {, pre-rigor } \\
\text { ground Hanwoo muscle was individually mixed with soybean } \\
\text { sauce solution (total salt concentration, } 0.5,1.0 \text {, and } 2.0 \% \text {, } \\
\text { respectively). }\end{array}$} \\
\hline
\end{tabular}

thiobarbituric acid (TBA) values. All the analysis was performed in triplicate.

\section{pH measurements}

The $\mathrm{pH}$ values of samples were measured in a homogenate prepared with $5 \mathrm{~g}$ of sample and distilled water $(20$ $\mathrm{mL}$ ) using a pH meter (Model 340, Mettler-Toledo GmbH, Switzerland). All determinations were performed in triplicate.

\section{Instrumental color evaluation}

Instrumental color was determined using a colorimeter (Minolta Chroma meter CR-210, Japan; illuminate C, calibrated with a white plate, $\mathrm{CIE} \mathrm{L}^{*}=+97.83, \mathrm{CIE} \mathrm{a}^{*}=-0.43$, $\left.C I E b^{*}=+1.98\right)$. Six measurements for each of five locations were taken. CIE L* (lightness), CIE a* (redness), and CIE $b^{*}$ (yellowness) values were recorded.

\section{Water holding capacity (WHC)}

Water holding capacity (WHC) was determined in triplicate by filter paper pressed method (Grau and Hamm, 1953). Sample of $0.3 \mathrm{~g}$ was weighed onto a Whatman No. 2 filter paper and pressed between two plexiglass plate for $3 \mathrm{~min}$. The areas of pressed water and sample were measured using planimeter (Koizumi, Type KP-21, Japan). WHC was calculated as follows:

$$
\begin{aligned}
\text { WHC }(\%)= & \text { area of pressed sample } \\
& \text { /area of pressed water } \times 100
\end{aligned}
$$




\section{Cooking loss}

All samples weighed (50 g) and were cooked in a constant-temperature water bath $\left(75^{\circ} \mathrm{C}, 30 \mathrm{~min}\right)$. The cooked samples were cooled to room temperature. After cooling, the cooked samples were reweighed. Cooking loss was determined by calculating the weight differences before and after cooking as follows.

\section{Cooking loss $(\%)$}

$=[$ weight of raw sample $(\mathrm{g})-$ weight of cooked sample $(\mathrm{g})) /$ weight of raw sample $(\mathrm{g})] \times 100$

\section{Total protein solubility}

The solubility of the total (sarcoplasmic + myofibrillar) protein was determined following the modification of procedures described by Helander (1957). To determine total soluble protein, $2 \mathrm{~g}$ of sample was weighed into a centrifuge tube, and then $20 \mathrm{~mL}$ of ice-cold 1.1 M KI in $0.1 \mathrm{M}$ phosphate buffer ( $\mathrm{pH}$ 7.4) was added. The sample and buffer were homogenized together on ice for $20 \mathrm{~s}$ using a homogenizer (Model AM-7, Nihonseiki Kaisha Ltd., Japan) set at 1,500 rpm, and were left to stand on a shaker in a dark room at $4^{\circ} \mathrm{C}$ overnight. The mixtures were centrifuged at $6,000 \mathrm{~g}$ for $15 \mathrm{~min}$ and the protein concentrations of the supernatants were determined by the biuret method (Gornall et al., 1949) using bovine serum albumin (Sigma Chemical Co., USA) as a standard.

\section{Myofibrillar fragmentation index (MFI)}

Myofibrils was obtained according to the method of Olson and Parrish (1976) using MFI buffer (20 mM $\mathrm{K}_{2} \mathrm{HPO}_{4} / \mathrm{KH}_{2} \mathrm{PO}_{4}$, pH 7.0, $100 \mathrm{mM} \mathrm{KCl,} 1$ mM EDTA, 1 $\mathrm{mM} \mathrm{NaN}$ ). The myofibrils were suspended in MFI buffer. An aliquot of myofibril suspension was diluted with the MFI buffer to $0.5 \mathrm{mg} / \mathrm{mL}$ protein concentration and the absorbance of this suspension measured at 540 $\mathrm{nm}$. MFI values were recorded as absorbance units per $0.5 \mathrm{mg} / \mathrm{mL}$ myofibril protein concentration multiplied by 200 .

\section{2-Thiobarbituric acid (TBA) value}

Lipid oxidation was assessed in triplicate by the TBA method of Tarladgis et al. (1960) with minor modifications. After manufacturing, all samples were stored at $4^{\circ} \mathrm{C}$ for $24 \mathrm{~h}$ for use of the analysis of lipid oxidation. A $10 \mathrm{~g}$ sample was blended with $50 \mathrm{~mL}$ distilled water for 2 min and then transferred to a distillation tube. The cup used for blending was washed with an additional $47.5 \mathrm{~mL}$ of distilled water, which was added to the same distilla- tion flask with $2.5 \mathrm{~mL} 4 \mathrm{~N} \mathrm{HCl}$ and a few drops of an antifoam agent (KMK-73, Shin-Etsu Silicone Co., Ltd., Korea). The mixture was distilled and $50 \mathrm{~mL}$ distillate was collected. $5 \mathrm{~mL}$ of $0.02 \mathrm{M}$ 2-thiobarbituric acid in $90 \%$ acetic acid (TBA reagent) was added to test tube containing $5 \mathrm{~mL}$ of the distillate and mixed well. The tubes were capped and heated in a boiling water bath for $30 \mathrm{~min}$ to develop the chromogen and cooled to room temperature. The absorbance was measured at $538 \mathrm{~nm}$, against a blank prepared with $5 \mathrm{ml}$ distilled water and 5 $\mathrm{mL}$ TBA-reagent, using a UV/VIS spectrophotometer (Optizen 2120 UV plus, Mecasys Co. Ltd., Korea). The TBA values were calculated as $\mathrm{mg}$ malondialdehyde (MDA)/kg meat.

$$
\begin{aligned}
& \text { TBA }(\text { MDA mg/kg) }=(\text { optical density of sample - } \\
& \text { optical density of blank) } \times 7.8
\end{aligned}
$$

\section{Texture profile analysis (TPA)}

Texture profile analysis (TPA) was performed at room temperature with a texture analyzer (TA-XT2 $i$, Stable Micro Systems, England). Cooked meat samples were taken from the central portion of each meat. Prior to analysis, samples were allowed to equilibrate to room temperature $\left(20^{\circ} \mathrm{C}, 3 \mathrm{~h}\right)$. The conditions of texture analysis were as follows: pre-test speed $2.0 \mathrm{~mm} / \mathrm{s}$, post-test speed 5.0 $\mathrm{mm} / \mathrm{s}$, maximum load $2 \mathrm{~kg}$, head speed $2.0 \mathrm{~mm} / \mathrm{s}$, distance $8.0 \mathrm{~mm}$, force $5 \mathrm{~g}$. The calculation of TPA values was obtained by graphing a curve using force and time plots. Values for hardness $(\mathrm{kg})$, springiness, cohesiveness, gumminess $(\mathrm{kg})$, and chewiness $(\mathrm{kg})$ were determined as described by Bourne (1978).

\section{Statistical analysis}

An analysis of variance was performed on all the variables measured using the General Linear Model (GLM) procedure of the SAS statistical package (SAS Institute, Inc., 1999). Duncan's multiple range test $(p<0.05)$ was used to determine differences between treatment means.

\section{Results and Discussion}

\section{The $\mathbf{p H}$ value and instrumental color evaluation}

Table 3 shows the $\mathrm{pH}$ and instrumental color of raw pre-rigor ground Hanwoo (Korean native cattle) muscle containing various salt concentrations in soybean sauce. The $\mathrm{pH}$ value is an important factor in raw meat and influences the quality characteristics of the final meat products (Park and Kwon, 1998). These are especially 
Table 3. Effect of salt concentration in soybean sauce on $\mathrm{pH}$ values and instrumental color of pre-rigor ground Hanwoo muscle

\begin{tabular}{lrrrrr}
\hline \hline \multirow{2}{*}{ Trait } & \multirow{2}{*}{ Control } & \multicolumn{3}{c}{ Treatments $^{1)}$} \\
\cline { 3 - 6 } & & \multicolumn{1}{c}{$\mathrm{TS}$} & \multicolumn{1}{c}{$\mathrm{T} 2$} & $\mathrm{~T}$ \\
\hline $\mathrm{pH}$ & $6.63 \pm 0.12^{\mathrm{A}}$ & $6.65 \pm 0.04^{\mathrm{A}}$ & $6.23 \pm 0.03^{\mathrm{B}}$ & $6.08 \pm 0.02^{\mathrm{C}}$ & $5.95 \pm 0.03^{\mathrm{D}}$ \\
$\mathrm{CIE} \mathrm{L}^{*}$ & $36.80 \pm 2.45^{\mathrm{A}}$ & $33.11 \pm 1.04^{\mathrm{B}}$ & $31.35 \pm 1.19^{\mathrm{BC}}$ & $31.26 \pm 1.19^{\mathrm{BC}}$ & $30.95 \pm 2.07^{\mathrm{C}}$ \\
$\mathrm{CIE} \mathrm{a}^{*}$ & $12.89 \pm 1.85^{\mathrm{C}}$ & $17.51 \pm 1.38^{\mathrm{A}}$ & $16.24 \pm 1.27^{\mathrm{B}}$ & $16.77 \pm 1.71^{\mathrm{AB}}$ & $16.85 \pm 1.67^{\mathrm{A}}$ \\
$\mathrm{CIE} \mathrm{b}^{*}$ & $8.04 \pm 0.64^{\mathrm{B}}$ & $7.16 \pm 0.43^{\mathrm{C}}$ & $7.13 \pm 0.65^{\mathrm{C}}$ & $7.66 \pm 0.64^{\mathrm{C}}$ & $9.41 \pm 0.80^{\mathrm{A}}$ \\
\hline
\end{tabular}

All values are mean \pm SD.

${ }^{\text {A-D }}$ Means in the same row with different letters are significantly different $(p<0.05)$.

${ }^{1)}$ Treatments: Control, pre-rigor ground Hanwoo muscle was mixed with ice water (total salt concentration, $0 \%$ ); TS, pre-rigor ground Hanwoo muscle was mixed with sodium chloride solution (total salt concentration, 2\%); T1, T2, and T3, pre-rigor ground Hanwoo muscle was individually mixed with soybean sauce solution (total salt concentration, $0.5,1.0$, and 2.0\%, respectively).

predominant aspects for pre-rigor muscle, where high $\mathrm{pH}$ values and ATP concentrations influence the processing quality of pre-rigor muscle (Hamm, 1977). The $\mathrm{pH}$ values of the control and TS were 6.63 and 6.65 , respectively. This result is in agreement with many previous studies, which have shown that the differences of $\mathrm{pH}$ value immediately after salting did not affected by $\mathrm{NaCl}$ concentration (Bernthal et al., 1989). Bernthal et al. (1989) reported that higher $\mathrm{NaCl}$ concentrations contributed to the formation of higher ultimate $\mathrm{pH}$ values in pre-rigor beef homogenates. Hamm (1977) suggested that the higher $\mathrm{pH}$ values of salted pre-rigor meat were due to the denaturation of glycolytic enzyme. However, the addition of soybean sauce solutions caused a significant decrease in the $\mathrm{pH}$ values of pre-rigor ground Hanwoo muscle even though the salt concentrations were higher $(p<0.05)$. At the same total salt concentration, T3 had significantly lower $\mathrm{pH}$ values than TS $(p<0.05)$. The $\mathrm{pH}$ value of soybean sauce solutions added to the $\mathrm{T} 1, \mathrm{~T} 2$, and $\mathrm{T} 3$ showed 5.26, 5.17, and 5.01, respectively. Jeon et al. (2002) reported that the low $\mathrm{pH}$ value of the soybean sauce is caused by the proliferation of lactic acid bacteria during the fermentation period, which might be the reason for a low $\mathrm{pH}$ value of meats treated with soybean sauce (T1, T2, and T3). A similar result was reported by Kim et al. (2011) where the $\mathrm{pH}$ value of frozen Hanwoo patties containing soybean sauce was lower than the $\mathrm{pH}$ value of those made with sodium chloride for both pre- and postrigor Hanwoo muscle.

The differences in lightness (CIE L $\left.{ }^{*}\right)$, redness $\left(\mathrm{CIE} \mathrm{a}^{*}\right)$, and yellowness (CIE $\left.{ }^{*}\right)$ values of pre-rigor Hanwoo by the addition of the soybean sauce were partially significant $(p<0.05)$. All treatments, regardless of salting materials, exhibited a significantly lower lightness and higher redness than the control $(p<0.05)$. A similar result was previously observed by Farouk and Swan (1997). In this study, they reported that pre-rigor salted minces had a darker and less yellow color than unsalted minces and suggested that salting and mincing decreased the lightness and yellowness due to an increase in lipid oxidation and protein denaturation in the muscle. T3 treatment had darker and T1 treatment had less red color than the TS treatment. When the soybean sauce was added to pre-rigor ground Hanwoo muscle, a higher yellowness value was observed as the addition level of soybean sauce increased, and the T3 treatment produced the highest yellowness value. These results were most likely due to the brown color of the soybean sauce, which may have contributed to the increase in the yellowness value of meat and meat products. Kim et al. (2011) reported that Hanwoo patties made with pre-rigor muscle and soybean sauce showed darker, less fiery, and browner when compared with sodium chloride treatments.

\section{The water holding capacity (WHC) and cooking loss}

The water holding capacity (WHC) of meat was affected by changes in various physical and biochemical factors such as the net charge effect, genetic factors, steric effects, and post-mortem proteolysis, especially, when the $\mathrm{pH}$ value was close to the isoelectric point of myofibrillar protein, which produced a poor WHC (Huff-Lonergan and Lonergan, 2005). Generally, the pre-rigor muscle had a superior WHC due to the high $\mathrm{pH}$ value and ATP concentration (Pisula and Tyburcy, 1996). In addition, the salted pre-rigor muscle had a higher WHC than unsalted pre-rigor muscle (Bernthal et al., 1989). Fig. 1 showed the WHC for raw pre-rigor ground Hanwoo (Korean native cattle) muscle containing various salt concentrations in soybean sauce. All treatments had a significantly higher WHC than the control $(p<0.05)$ except T1 which was not significantly differences from the control $(p>0.05)$. The "pre-rigor salting effect" which leads to high functional- 


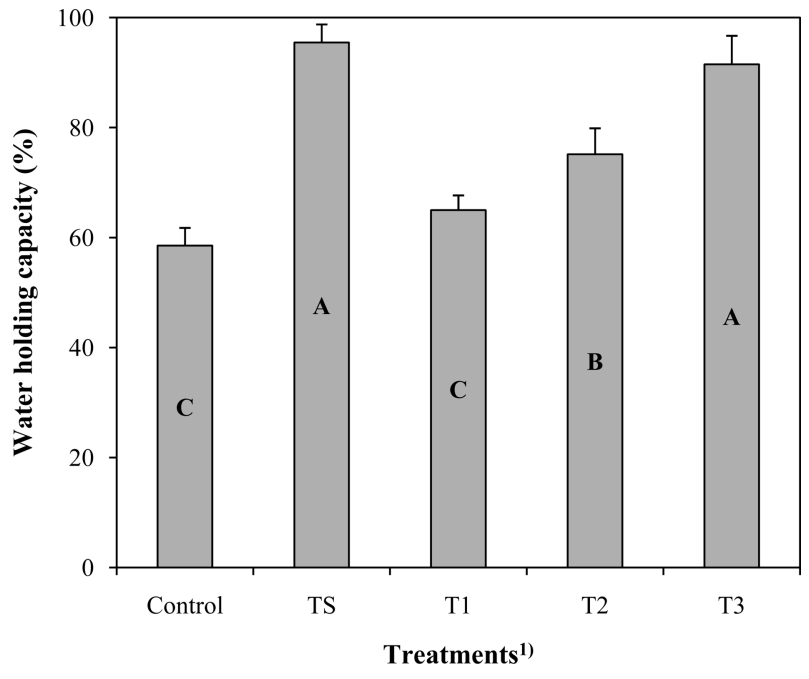

Fig. 1. Effects of salt concentration in soybean sauce on water holding capacity of pre-rigor ground Hanwoo muscle. ${ }^{1)}$ Treatments: Control, pre-rigor ground Hanwoo muscle was mixed with ice water (total salt concentration, $0 \%$ ); TS, pre-rigor ground Hanwoo muscle was mixed with sodium chloride solution (total salt concentration, 2\%); T1, T2, and T3, pre-rigor ground Hanwoo muscle was individually mixed with soybean sauce solution (total salt concentration, $0.5,1.0$, and $2.0 \%$, respectively).

ity of pre-rigor muscle was observed in a previous study at least $1.8 \%$ (Hamm, 1981) or $2.0 \%$ (Bernthal et al., 1989) of a $\mathrm{NaCl}$ concentration. The WHC of pre-rigor Hanwoo treated with soybean sauce was consistently increased as the salt concentration in the soybean sauce increased, and $\mathrm{T} 3$ treatment having the lowest $\mathrm{pH}$ value had the eventually a higher WHC when compared with $\mathrm{T} 1$ and $\mathrm{T} 2$. This phenomenon resulted from the increased salt concentration rather than $\mathrm{pH}$ effect; thus, the $\mathrm{WHC}$ of pre-rigor muscle containing soybean sauce was more affected by the salt concentration than their low $\mathrm{pH}$ values. A similar result was reported by Bernthal et al. (1989), who found that pre-rigor ground treated with 2 and $4 \% \mathrm{NaCl}$ had a higher WHC than the other $\mathrm{NaCl}$ treatments $(0.0,0.5$, and $1.0 \%)$.

The cooking loss of pre-rigor ground Hanwoo muscle containing various salt concentrations in soybean sauce is shown in Fig. 2. The control had the highest cooking loss among the treatments whereas TS had a lower cooking loss than the soybean sauce treatments $(p<0.05)$. However, an increase of salt concentration in the soybean sauce resulted in lowering the cooking loss of pre-rigor ground Hanwoo meat. Farouk and Swan (1997) reported that batters prepared with pre-rigor salted mince had a higher cooking yield than those made with unsalted

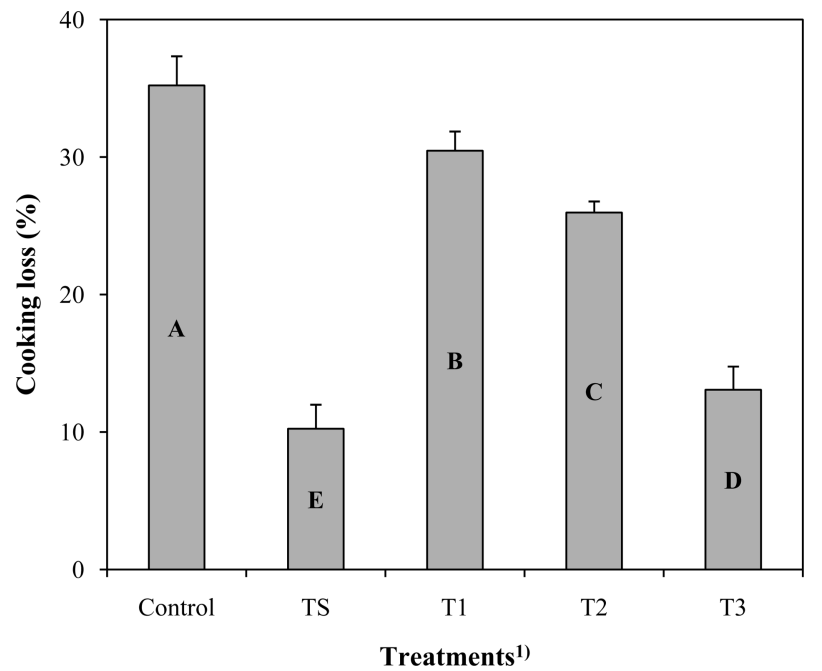

Fig. 2. Effects of salt concentration in soybean sauce on cooking loss of pre-rigor ground Hanwoo muscle. ${ }^{1)}$ Treatments: Control, pre-rigor ground Hanwoo muscle was mixed with ice water (total salt concentration, $0 \%$ ); TS, pre-rigor ground Hanwoo muscle was mixed with sodium chloride solution (total salt concentration, 2\%); T1, T2, and T3, pre-rigor ground Hanwoo muscle was individually mixed with soybean sauce solution (total salt concentration, $0.5,1.0$, and $2.0 \%$, respectively).

mince. Bernthal et al. (1989) suggested that the increase in cooking yield of pre-rigor meat by the addition of salt may be due to a high WHC. Similarly, Offer and Trinick (1983) and Paterson et al. (1988) suggested that salt could influence the net charge and meat protein solubility in the muscle. Our results were similar to those of previous reports, which demonstrated that a lower cooking loss by increasing the salt levels of soybean sauce in pre-rigor ground Hanwoo meat resulted from an increase in the WHC. Furthermore, these results suggest that the addition of soybean sauce to pre-rigor Hanwoo muscle showed similar effects as seen on salting the muscle with sodium chloride at same salt concentration.

\section{The total protein solubility and myofibrillar frag- mentation index (MFI)}

The total protein solubility and myofibrillar fragmentation index (MFI) are shown in Table 4. Statistical analysis indicated that TS had the highest total protein solubility, and increases of the salt concentration in soybean sauce resulted in gradually an increase in the total protein solubility $(p<0.05)$. A similar result was reported by Bernthal et al. (1991) who found that an increase in extractable protein was observed when the $\mathrm{NaCl}$ concentrations in ground beef were increased. With related to rigor status, Farouk and Swan (1997) reported that pre-rigor muscle 
Table 4. Effect of salt concentration in soybean sauce on total protein solubility and $\mathrm{MFI}^{1)}$ of pre-rigor ground Hanwoo muscle

\begin{tabular}{lccccc}
\hline \multirow{2}{*}{ Trait } & \multirow{2}{*}{ Control } & \multicolumn{3}{c}{ Treatments $^{2)}$} \\
\cline { 3 - 6 } & & TS & T1 & T2 & T3 \\
\hline Total protein solubility $(\mathrm{mg} / \mathrm{g})$ & $55.06 \pm 2.34^{\mathrm{E}}$ & $75.36 \pm 1.72^{\mathrm{A}}$ & $60.42 \pm 2.71^{\mathrm{D}}$ & $66.84 \pm 2.79^{\mathrm{C}}$ & $70.12 \pm 1.51^{\mathrm{B}}$ \\
MFI & $20.35 \pm 1.02^{\mathrm{B}}$ & $14.67 \pm 1.53^{\mathrm{C}}$ & $15.30 \pm 0.74^{\mathrm{C}}$ & $30.95 \pm 2.07^{\mathrm{A}}$ & $32.26 \pm 1.19^{\mathrm{A}}$ \\
\hline
\end{tabular}

All values are mean $\pm \mathrm{SD}$.

${ }^{A-E}$ Means in the same row with different letters are significantly different $(p<0.05)$.

${ }^{1)}$ MFI: myofibrillar fragmentation index

${ }^{2}$ Treatments: Control, pre-rigor ground Hanwoo muscle was mixed with ice water (total salt concentration, $0 \%$ ); TS, pre-rigor ground Hanwoo muscle was mixed with sodium chloride solution (total salt concentration, 2\%); T1, T2, and T3, pre-rigor ground Hanwoo muscle was individually mixed with soybean sauce solution (total salt concentration, $0.5,1.0$, and 2.0\%, respectively).

had higher protein (as actin and actomyosin) extractability than post-rigor muscle and Trautman (1966) also found that the decrease in $\mathrm{pH}$ was associated with a linear decrease in protein solubility. However, in this study, although the lowest $\mathrm{pH}$ value was observed in $\mathrm{T} 3$ treatment, T3 had the highest total protein solubility among the samples containing soybean sauce. This result indicates that the total protein solubility of pre-rigor meat, especially the salt-soluble proteins, was more influenced by increasing effects of the salt concentration in the soybean sauce rather than the lowering of the $\mathrm{pH}$ by soybean sauce.

The myofibrillar fragmentation index (MFI) is related to the degradation of myofibrils in the vicinity of the Zdisc during aging or ripening (Olson and Parrish, 1976) Parrish et al. (1973) reported that the development of MFI was affected by the storage periods and temperature. In addition, changes in the quality of meat post-mortem relative to the degradation of myofibrillar proteins are mainly influenced by endogenous proteinases, and degradation of myofibrillar proteins is an important factor in meat tenderness including sarcomere length, ionic strength, and characteristics of animals (Koohmaraie, 1994). The TS and T1 had the lowest MFI and T2 and T3 showed the highest MFI $(p<0.05)$, while the control was in between. Sárraga et al. (1989) suggested that the presence of $\mathrm{NaCl}$ may inhibit enzyme activity such as Ca-dependent pro- tease, cathepsin $\mathrm{D}$ and $\mathrm{L}$ in porcine muscle. According to Song et al. (2001), protease activity in soybean sauce is decreased by heat sterilization, however, was recovered during storage. Thus, higher MFI of T2 and T3 in this study may be affected by various proteases, produced from microorganisms during the fermentation process of soybean sauce (Baek et al., 2010).

\section{2-Thiobarbituric acid (TBA) values}

The 2-thiobabituric acid (TBA) values of pre-rigor ground Hanwoo muscle containing various salt concentrations in soybean are shown in Table 5. Generally, the addition of salt to meat and meat products promotes lipid oxidation. In a previous study, Torres et al. (1988) reported that $\mathrm{NaCl}$ at a concentration of at least $0.5 \%$ catalyzed lipid oxidation in pre-rigor beef muscle. In addition, Lee et al. (1997) reported that the accelerated lipid oxidation through the addition of sodium chloride was due to the release of iron ions from heme pigments in myoglobin. In this study (Table 5), it seems likely that the addition of sodium chloride rather than soybean sauce treatment to the pre-rigor ground Hanwoo meat is at least responsible for elevating the TBA values. TS produced with $2.0 \%$ of sodium chloride had the highest TBA values than the control and the soybean sauce treatments (T1, T2, and T3). However, the addition of soybean sauce (T2 and T3) at greater than 1.0\% lowered the TBA values

Table 5. Effect of salt concentration in soybean sauce on $\mathrm{TBA}^{1)}$ values of pre-rigor ground Hanwoo muscle after $24 \mathrm{~h}$ of processing

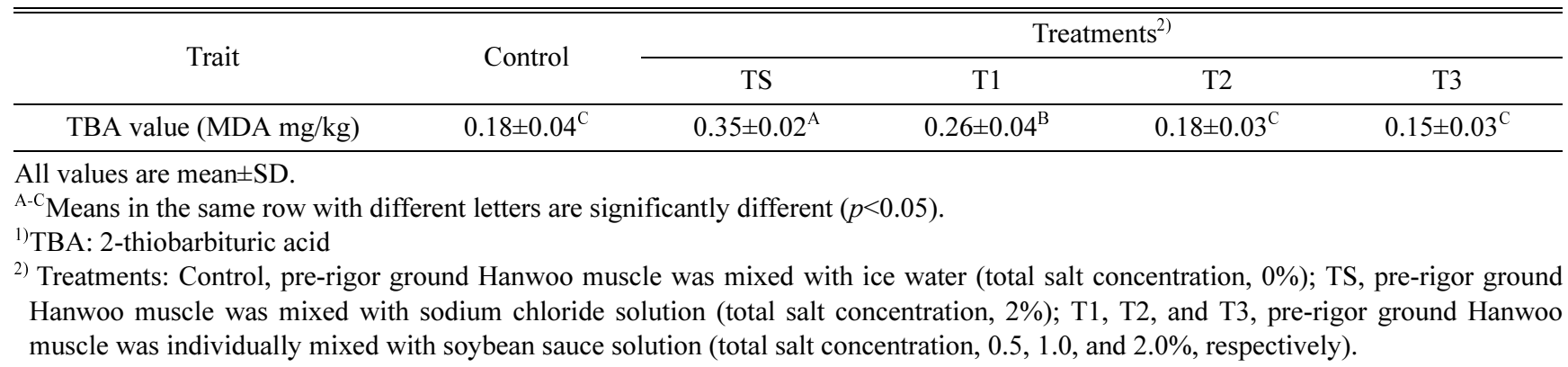


Table 6. Effect of salt concentration in soybean sauce on textural properties of cooked pre-rigor ground Hanwoo muscle

\begin{tabular}{lccccc}
\hline \hline \multirow{2}{*}{ Trait } & Control & \multicolumn{4}{c}{ Treatments $^{1)}$} \\
\cline { 3 - 6 } & & TS & T1 & T2 & T3 \\
\hline Hardness (kg) & $0.78 \pm 0.04^{\mathrm{D}}$ & $0.98 \pm 0.08^{\mathrm{A}}$ & $0.83 \pm 0.06^{\mathrm{C}}$ & $0.95 \pm 0.05^{\mathrm{B}}$ & $1.02 \pm 0.10^{\mathrm{A}}$ \\
Springiness & $0.73 \pm 0.04^{\mathrm{B}}$ & $0.83 \pm 0.04^{\mathrm{A}}$ & $0.74 \pm 0.05^{\mathrm{B}}$ & $0.77 \pm 0.07^{\mathrm{AB}}$ & $0.82 \pm 0.04^{\mathrm{A}}$ \\
Cohesiveness & $0.47 \pm 0.06^{\mathrm{C}}$ & $0.62 \pm 0.05^{\mathrm{A}}$ & $0.47 \pm 0.05^{\mathrm{C}}$ & $0.58 \pm 0.07^{\mathrm{B}}$ & $0.64 \pm 0.03^{\mathrm{A}}$ \\
Gumminess (kg) & $0.40 \pm 0.04^{\mathrm{C}}$ & $0.64 \pm 0.06^{\mathrm{A}}$ & $0.41 \pm 0.06^{\mathrm{C}}$ & $0.50 \pm 0.04^{\mathrm{B}}$ & $0.66 \pm 0.10^{\mathrm{A}}$ \\
Chewiness (kg) & $0.29 \pm 0.08^{\mathrm{C}}$ & $0.54 \pm 0.06^{\mathrm{A}}$ & $0.30 \pm 0.05^{\mathrm{C}}$ & $0.45 \pm 0.04^{\mathrm{B}}$ & $0.56 \pm 0.07^{\mathrm{A}}$ \\
\hline
\end{tabular}

All values are mean \pm SD.

A-D Means in the same row with different letters are significantly different $(p<0.05)$.

${ }^{1)}$ Treatments: Control, pre-rigor ground Hanwoo muscle was mixed with ice water (total salt concentration, $0 \%$ ); TS, pre-rigor ground Hanwoo muscle was mixed with sodium chloride solution (total salt concentration, 2\%); T1, T2, and T3, pre-rigor ground Hanwoo muscle was individually mixed with soybean sauce solution (total salt concentration, $0.5,1.0$, and $2.0 \%$, respectively).

of pre-rigor ground Hanwoo meat, which are similar ( $p>0.05)$ to the control. Torres et al. (1988) reported that TBA values in pre-rigor beef muscle were increased when the $\mathrm{NaCl}$ concentration was increased from 0.0 to $4.0 \%$. Our results partially agree with the findings of their previous research (as in between the control and TS treatment). However, the T3 treatment, which had a salt concentration of $2.0 \%$, produced the lowest TBA values relative to the other treatments, and the $\mathrm{T} 1 \mathrm{had}$ a higher TBA value compared to the control. At $0.5 \%$ of salt concentration in soybean sauce (T1), salt has a greater impact on the lipid oxidation than the antioxidative effect of soybean sauce. Moon and Cheigh (1986) reported similar results for ground beef cooked by microwave heating, and Shin and Lee (1990) also demonstrated that the antioxidative properties of soybean sauce were the highest among various seasonings. The results obtained in this study may be due to the presence of the antioxidative compounds in soybean sauce, such as melanoidin, phenolic compounds, and nitrogen based compounds (Moon, 1991). Also, Jeon et al. (2002) indicated that the antioxidative properties of soybean sauce were related to melanoidin, which is formed by the maillard reaction.

\section{Texture profile analysis (TPA)}

Table 6 shows the effects of salt concentration in soybean sauce on the texture properties of the pre-rigor ground Hanwoo muscle. The TS and T3 treatments had the highest values for all textural properties $(p<0.05)$, and they were not significant $(p>0.05)$. Similar result was obtained by Kim et al. (2011). In the case of soybean sauce treatments (T1, T2, and T3), the hardness was higher as the salt concentration in soybean sauce increased $0.5 \%$ to $2.0 \%(p<0.05)$. Knight (1992) reported that the addition of salt and phosphate enhanced the hardness due to the increased ionic strength and Claus et al. (1989) reported that an increase in the amount of salt soluble proteins tended to increase the hardness of the meat products. Similar results were reported by Claus and Sørheim (2006) and Mann et al. (1990). Knight (1992) reported that when the salt concentration in ground meat products was increased, the hardness increased and the structure changed substantially with the increased ionic strength. For these reasons, T3 had more firmness due to improve binding ability of meat particles as well as a higher WHC and MFI. In addition, the increase of salt concentration in soybean sauce significantly $(p<0.05)$ influenced the increase in springiness, cohesiveness, gumminess, and chewiness of pre-rigor ground Hanwoo meat between T1 and T3.

The objective of this study was to investigate the effect of salt concentration in soybean sauce on the physicochemical properties of pre-rigor ground Hanwoo muscles. The WHC, cooking loss, total protein solubility, MFI, and textural properties of pre-rigor Hanwoo muscle were improved at a higher salt concentration in the soybean sauce. Also, the addition of soybean sauce was more effective at inhibiting the lipid oxidation. Although the soybean sauce produced a comparatively lower cooking loss and total protein solubility than sodium chloride at the same salt concentration, the soybean sauce can be used as a good curing source, considering the improvements in MFI and lipid oxidation of the pre-rigor ground Hanwoo muscle when treated with soybean sauce.

\section{Acknowledgement}

This work was supported by the Konkuk University.

\section{References}

1. Baek, S. Y., Yun, H. J., Choi, H. S., Koo, B. S., and Yeo, S. H. (2010) Isolation and physiological characteristics of micro- 
organisms producing extracellular enzymes from Korean traditional soybean sauce and soybean paste. Kor. J. Microbiol. Biotechnol. 38, 379-384.

2. Bernthal, P. H., Booren, A. M., and Gray, J. I. (1989) Effect of sodium chloride concentration on $\mathrm{pH}$, water-holding capacity and extractable protein of prerigor and postrigor ground beef. Meat Sci. 25, 143-154.

3. Bernthal, P. H., Booren, A. M., and Gray, J. I. (1991) Effect of reduced sodium chloride concentration and tetrasodium pyrophosphate on $\mathrm{pH}$, water-holding capacity and extractable protein of prerigor and postrigor ground beef. Meat Sci. 29, 69-82.

4. Boles, J. A. and Swan, J. E. (1997) Effects of brine ingredients and temperature on cook yields and tenderness of prerigor processed roast beef. Meat Sci. 45, 87-97.

5. Bourne, M. C. (1978) Texture profile analysis. Food Technol. 32, 62-66.

6. Choi, H. S., Lee, J. S., Moon, G. S., and Park, G. Y. (1990) Antioxidative characteristics of fermented soybean sauce on the oxidation of fatty acid mixture. Korean J. Food Sci. Technol. 22, 332-336.

7. Choi, Y. S., Jeong, J. Y., Choi, J. H., Lee, M. A., Lee, E. S., Kim, H. Y., Han, D. J., Kim, J. M., and Kim, C. J. (2006) Effects of immersion period after tumbling processing on the quality properties of boiled pork loin with soy sauce. Korean J. Food Cookery Sci. 22, 379-385.

8. Claus, J. R. and Sørheim, O. (2006) Preserving pre-rigor meat functionality for beef patty production. Meat Sci. 73, 287-294.

9. Claus, J. R., Hunt, M. C., and Kastner, C. L. (1989) Effects of substituting added water for fat on the textural, sensory, and processing characteristics of bologna. J. Muscle Food $\mathbf{1}$, $1-21$.

10. Farouk, M. M. and Swan, J. E. (1997) Effect of pH at time of salting on the functional properties of pre-rigor beef. Meat Sci. 45, 463-472.

11. Gornall, A. G., Bardawill, C. J., and David, M. M. (1949) Determination of serum proteins by means of the biuret reaction. J. Biol. Chem. 177, 751-766.

12. Grau, R. and Hamm, R. (1953) Eine einfache methode zur bestimmung der wasserbindung im muskel. Natruwissenschaften 40, 29-30.

13. Hamm, R. (1977) Postmortem breakdown of ATP and glycogen in ground muscle: A review. Meat Sci. 1, 15-39.

14. Hamm, R. (1981) Postmortem changes in muscle affecting the quality of comminuted meat products. In: Development in meat Science. Lawrie, R. (ed), Applied Science Publishers Limited, London, Vol. 2, pp. 93-124.

15. Helander, E. (1957) On quantitative muscle protein determination. Acta Physiol. Scand. 41, 1-99.

16. Huff-Lonergan, E. and Lonergan, S. M. (2005) Mechanisms of water-holding capacity in meat: The role of postmortem biochemical and structural changes. Meat Sci. 71, 194-204.

17. Jeon, M. S., Sohn, K. H., Chae, S. H., Park, H. K., and Jeon, H. J. (2002) Color characteristics of Korean traditional soy sauces prepared under different processing conditions.
Korean Soc. Food Sci. Nutr. 31, 32-38.

18. Jin, S. K., Kim, I. S., Hur, S. J., Lyou, H. J., Hah, K. H., Joo, S. T., and Lee, J. I. (2004) Physico-chemical changes of pork prepared by Korean traditional sauces during chilled aging. Korean J. Anim. Sci. Technol. 46, 859-870.

19. Kim, D. H., Jo, C., Yook, H. S., Park, B. J., and Byun, M. W. (2002) Enhancement of preservation characteristics of Meju, and intermediate material for Korean legume-based fermented soy sauce, Kanjang, by irradiation. Radiat. Phys. Chem. 64, 317-322.

20. Kim, H. W., Choi, J. H., Choi, Y. S., Han, D. J., Kim, H. Y., Lee, M. A., Kim, S. Y., and Kim, C. J. (2011) Effects of soybean sauce and pre-rigor muscle on physicochemical properties of frozen Hanwoo patties. Korean J. Food Sci. Ani. Resour. 31, 19-26.

21. Knight, M. K. (1992) Red meat and poultry surimi. In: The chemistry of muscle-based foods. Johnston, D. E., Knight, M. K., and Ledward, D. A. (eds). Redwood Press Ltd, Wiltshire, England, pp. 222-265.

22. Koohmaraie, M. (1994) Muscle proteinases and meat aging. Meat Sci. 36, 93-104.

23. Lee, S. K., Mei, L., and Decker, E. A. (1997) Influence of sodium chloride on antioxidant enzyme activity and lipid oxidation in frozen ground pork. Meat Sci. 46, 349-355.

24. Mann, T. F., Reagan, J. O., Johnson, L. P., Lyon, C. E., Mabry, J. W., and Miller, M. F. (1990) Textural and chemical characteristics of recombined precooked beef chuck roasts as influenced by boning time and salt level. J. Food Sci. 55, 330-333.

25. Moon, G. S. (1991) Comparison of various kinds of soybean sauces on their antioxidative activities. J. Korean Soc. Food Nutr. 20, 582-589.

26. Moon, G. S. and Cheigh, H. S. (1986) Antioxidative effect of soybean sauce on the lipid oxidation of cooked meat. Korean J. Food Sci. Technol. 18, 313-318.

27. Offer, G. and Trinick, J. (1983) On the mechanism of water holding in meat: The swelling and shrinking of myofibrils. Meat Sci. 8, 245-281.

28. Olson, D. G. and Parrish, F. C., Jr. (1976) Relationship of myofibril fragmentation index to measures of beef steak tenderness. J. Food Sci. 42, 506-509.

29. Park, S. W. and Kwon, S. K. (1998) Sensory characteristics and tenderness of boiled beef by addition of the Bark (Morus alba Linne). Korean J. Food. Nutr. 11, 580-584.

30. Parrish, F. C., Jr., Young, R. B., Miner, B. E., and Andersen, L. D. (1973) Effect of postmortem conditions on certain chemical, morphological and organoleptic properties of bovine muscle. J. Food Sci. 38, 690-695.

31. Paterson, B. C., Parrish, F. C., and Stromer, M. H. (1988) Effects of salt and pyrophosphate on the physical and chemical properties of beef muscle. J. Food Sci. 53, 1258-1265.

32. Pisula, A. and Tyburcy, A. (1996) Hot processing of meat. Meat Sci. 43, S125-S134.

33. Sárraga, C., Gil, M., Arnau, J., and Monfort, J. M. (1989) Effect of curing salt and phosphate on the activity of porcine muscle protease. Meat Sci. 25, 241-249. 
34. SAS. (1999) SAS/STAT Software. Release 8.1, SAS Institute Inc., Cary, NC, USA.

35. Shim, S. L., Ryo, K. Y., Kim, W., Jun, S. N., Seo, H. Y., Han, K. J., Kim, J. H., Song, H. P., Cho, N. C., and Kim, K. S. (2008) Physicochemical characteristics of medicinal herbs Ganjang. Korean J. Food Preserv. 15, 243-252.

36. Shin, D. K. and Lee, Y. O. (1990) Antioxidative effect of seasoning on the lipid oxidation of Bulgogi cooked meat. J. Kor. Oil Chemist's Soc. 7, 75-81.

37. Song, T. H., Kim, D. H., Park, B. J., Shin, M. G., and Byun, M. W. (2001) Changes in microbiological and general quality characteristics of gamma irradiated Kanjang and Shoyu.
Korean J. Food Sci. Technol. 33, 338-344.

38. Tarladgis, B. G., Watts, B. M., Younathanm, M. T., and Dugan, L. (1960) A distillation method for the quantitative determination of malonaldehyde in rancid foods. J. Am. Oil Chem. Soc. 37, 44-52.

39. Torres, E., Pearson, A. M., Gray, J. I., Booren, A. M., and Shimokomaki, M. (1988) Effect of salt on oxidative changes in pre- and post-rigor ground beef. Meat Sci. 23, 151-163.

40. Trautman, J. C. (1966) Effect of temperature and $\mathrm{pH}$ on the soluble proteins of ham. J. Food. Sci. 31, 409-418.

(Received 2011.4.17/Revised 2011.5.19/Accepted 2011.6.7) 